\title{
Dual genitotropic human papillomavirus infections in genital warts
}

\author{
J Aznar, A Ojeda, M J Torres, J C Palomares, A Rodriguez-Pichardo
}

\begin{abstract}
Background and methods-We have carried out a prospective study of dual genitotropic human papillomavirus (HPV) infections by means of two different DNA detection methods in biopsy specimens obtained from patients who were examined for genital warts at the STD clinic of the School of Medicine in Seville, between January 1990 and December 1991.

Results-100 patients with a clinical diagnosis of condilomata acuminata were seen during the study period. DNA of the genitotropic HPV $6 / 11,16 / 18$ and $31 / 33 / 35$ was detected by an in situ hybridisation method in $75(77 \%)$ of the 98 evaluable samples; one of the genotypes tested in 59 (61\%) samples, and two or more genotypes tested in the remaining $16(15 \%)$ samples. In 21 (98\%) of the 23 negative samples by in situ hybridisation, we were able to detect DNA of genital HPV using a polymerase chain reaction amplification method (PCR). Among the 34 samples where PCR was applied we confirmed the presence of two different HPV genotypes in eight samples.
\end{abstract}

Conclusions-The frequency of dual infections with human genitotropic papillomavirus in genital warts was $8 \%$, although we believe that this rate should be higher as we have not used the PCR method in all of the samples.

(Genitourin Med 1993;69:60-62)

\section{Introduction}

Condyloma acuminatum is the most common viral sexually transmitted disease in Western countries. ${ }^{1-8}$ These genital warts are caused by human papillomavirus (HPV) infection of the anogenital squamous epithelium. Often, but not always, specific HPVs are associated with distinct clinical and histopathologic characteristics, such as HPV-6 or -11 with condylomata and HPV-16 with squamous-cell precancers and carcinomas. ${ }^{9-11}$ These associations are not invariable, as HPV- 6 has been found in anogenital squamous cell carcinomas and HPV-16 in some cutaneous condylomata. ${ }^{12}$

There is a paucity of data about dual infections with genital HPVs on condylomata acuminata, and there is not agreement about the rates of multiple infections (with genitotropic HPVs) ranging from none ${ }^{13}$ to $13 \% .{ }^{14-16}$ The aims of the study were to know the prevalence of different genital HPV geno- types in genital warts in Spain, to know the rate of dual infections in these patients, and finally to compare two methods for the detection of DNA HPV in genital warts and design a laboratory strategy for the diagnosis of genital HPV infections in a clinical setting.

\section{Material and methods}

Condyloma specimens. Anogenital condyloma tissues were collected from 100 patients attending the STD Clinic of the School of Medicine in Seville. Condyloma acuminatum was diagnosed by gross appearance of the lesion and clinical history of the patient (table 1). The tissue available for laboratory analyses was usually a shave or punch biopsy. Half of the specimen was fixed in neutral $10 \%$ formalin for in situ hybridisation, while the other half was frozen at $-70^{\circ} \mathrm{C}$ for PCR.

In situ hybridisation (ISH). Formalin-fixed tissue sections $(10 \mu \mathrm{m}$ thick) were hybridised with biotinylated HPV-6/11, or $-16 / 18$, or $-31 / 33 / 35$ in stringent conditions ${ }^{14}$ using a commercial kit Enzo PathoGene (Enzo Diagnostics, Inc). Hybridised DNA was detected by sequential immunocytochemical reactions and visualised with a light microscope. Manufactuer's instructions were followed explicitly.

Polymerase Chain Reaction (PCR). The thawed specimens were minced and dissolved at $37^{\circ} \mathrm{C}$ in lysis buffer containing $50 \mathrm{mM}$ Tris$\mathrm{HCl}, \mathrm{pH} 7.5,0.5 \%$ SDS, $10 \mathrm{mM}$ EDTA, $50 \mathrm{mM} \mathrm{NaCl}$ and $150 \mu \mathrm{g}$ Proteinase K. After phenol and ethanol precipitation the DNA was pelleted by centrifugation. The pellet was dried and dissolved in $300 \mu \mathrm{l}$ distilled water. PCR was performed as described previously. ${ }^{17}$ The sequences for oligonucleotide consensus amplification and type-specific primers and probes were derived from conserved regions of the L1 open-reading frames of HPV-11, -16, -18; L2 of HPV-6 and E1 of HPV-33. These sequences have been described elsewhere. ${ }^{18-20}$

Table 1 Demographic characteristic of 98 patients and genital site of the lesions

\begin{tabular}{ll}
\hline Patients: & 77 \\
Male & 21 \\
Female & $29 \cdot 7$, SD $9 \cdot 4(17-76 \mathrm{ys})$ \\
Age & \\
Location of the Lesions: & 75 \\
External genitalia: & 57 \\
$\quad$ Male patients & 18 \\
Female patients & \\
Perineal region: & 20 \\
$\quad$ Male patients & 3 \\
Female patients & $6 \cdot 02$, SD 4.86 (1-25) \\
Number of Lesions: & \\
\hline
\end{tabular}

Medicine, University of Seville, Apdo 914, 41080 Sevilla, Spain J Aznar 
Table 2 Sex distribution and prevalence of HPV genotypes as determined in situ hybridization method

\begin{tabular}{llllll}
\hline \multicolumn{5}{c}{ HPV Genotype } \\
\cline { 2 - 6 } Patients & $6 / 11$ & $16 / 18$ & $31 / 35$ & $\begin{array}{l}\text { Mixed } \\
\text { infection }\end{array}$ & None \\
\hline Males (n=77) & 44 & 1 & 2 & 13 & 17 \\
Females (n = 21) & 12 & - & $\frac{1}{2}$ & 3 & 6 \\
Total (n= 98) & 56 & 1 & 2 & 16 & 23 \\
\hline
\end{tabular}

The PCR reactions were performed in an automated thermocycler programmed for 32 cycles of DNA denaturation $\left(95^{\circ} \mathrm{C}\right)$, primer annealing $\left(55^{\circ} \mathrm{C}\right)$, and template extension $\left(72^{\circ}\right){ }^{21}$ PCR products were tranferred to nitrocellulosed and hybridised with specific (for 6, 11, 16, 18, and 33) oligometric probes. To avoid contamination, the PCR was performed in several separate work stations, the reagents were aliquoted from master mixes and the samples were added using piston-driven pipettes. Solution control without added DNA was included. Low positive control was DNA extracted from Hep-2 cells and negative control was DNA extracted from MRC-5 cells.

\section{Results}

In situ hybridisation (IHS): Of the 98 biopsy specimens evaluated, 75 (77\%) showed evidence of infection with HPV types tested using the ISH method. Among these samples, we detected only one genotype in $59(61 \%)$ samples while two or more genotypes were found in the remaining $16(16 \%)$ (table 2$)$. The genotype distribution found in the dual infections is summarised in table 3 . The overall prevalence of the HPV-6/11,-16/18 and $-31 / 35$ was $76 \%, 8 \%$ and $15 \%$ respectively. None of the women had HPV-16/18 infection, and in the three who had HPV-31/35 infection was associated with HPV-6/11. All but one of the HPV-16/18 infections detected in male patients were associated with other genotypes. HPV-31/35, infection was detected in 15 patients, but in thirteen of them it was associated to other genotypes.

DNA amplification (PCR): Of the 23 ISHnegative samples, 21 (98\%) showed evidence of genitotropic HPV infection by means of PCR using a consensus primer. Sixteen of them were positive for HPV- 6 type specific primer, one for HPV-11, three for HPV-6 and -11 , and one for HPV-6 and -33. Of the 16 dual infections detected by ISH we have only been able to confirm four of them by PCR assays: two of them due to HPV- 6 and -11 , one by HPV-11 and -18, and one by HPV-11 and 33 ; and in three samples we were not able to

Table 3 Genotype distribution found in the dual infections by in situ hybridisation method

\begin{tabular}{|c|c|c|c|c|}
\hline \multirow[b]{2}{*}{ Patients } & \multicolumn{4}{|c|}{ HPV Genotype } \\
\hline & $6 / 11,16 / 18$ & $6 / 11,31 / 35$ & $16 / 18,31 / 35$ & $6 / 11,16 / 18,31 / 35$ \\
\hline $\begin{array}{l}\text { Males }(n=13) \\
\text { Females }(n=3)\end{array}$ & 3 & $\begin{array}{l}6 \\
3\end{array}$ & 1 & 3 \\
\hline Total $(n=16)$ & 3 & 9 & $\overline{1}$ & $\overline{3}$ \\
\hline
\end{tabular}

detect any of the genotypes tested two of them being positive with the consensus primer but type specific negative.

After combining the results of the two techniques, we demonstrated DNA of genitotropic HPV in 95 out of 98 samples $(97 \%)$. DNA HPV-6/11 in 82 (84\%), DNA HPV$16 / 18$ in one $(1 \%)$, DNA HPV-31/33/35 in two (2\%), DNA consensus primer in two $(2 \%)$, and eight $(8 \%)$ dual infections.

\section{Discussion}

The present report is the result of a prospective study designed to determine the rates of the different genitotropic HPV genotypes in 100 patients diagnosed of condylomata acuminata in Spain. We found that HPV-6 and -11 genotypes are the most commonly associated with anogenital cutaneous condylomata ${ }^{121322-24}$ as previously described. Estimates of the proportion of condylomata positive for HPV-16/18 and HPV-31/33/35 range from none to $10 \%^{13-16}$ and in our study were $2 \%$ and $4 \%$ respectively. We also confirm the limited sensitivity $(77 \%)$ of the ISH method $^{225-27}$ and the poor specificity of the commercial kit we used due to the cross reactivity of the different probes, specially HPV types $-16 / 18$ and $-31 / 33 / 35$, because only four of the 16 dual infections detected by ISH could be confirmed by PCR assays. In addition, this method does not distinguish double infections if the types are in the same probing group (eg a -6 and -11 double infection). ${ }^{20}$

Rates of dual infections range from none or $<1 \%^{13-15}$ to $13 \%$ or more; ${ }^{16-24}$ our rate is $8 \%$ but it is difficult to compare the results as these investigations used different populations and methods, and generalisation among them cannot be made. Even though we believe that the rate of dual infections should be higher as far as using PCR, we have been able to detect four dual infections among the 23 negative samples by ISH.

We consider that in order to know the true prevalence of dual infection it should be convenient to apply a PCR assay that combines consensus and type-specific primers for the genitotropic HPVs, and the studies similar to ours can contribute to the knowledge of epidemiology and pathogenesis of HPV genitoanal infections.

1 Chuang T, Perry HO, Kurlanc LT et al. Condylom acuminatum in Rochester, Minnesota, 1950-1978. Arch Dermatol 1984;120:469-75.

2 Public Health Laboratory Service Communicable Disease Surveillance Centre. Sexually transmitted disease in Britain: 1985-6. Genitourin Med 1989;65:117-21

3 Beuter KR, Becker TM, Stone KM. Epidemiology of human papillomavirus infections. In: Human papillomavirus infections. Dermatologic Clinics 1991;9:211-18.

4 Centers for Disease Control: Condylomata acuminataUnited States. MMWR. 1983;32:306-8.

5 Chief Medical Officer, Department of Health and Social Security, United Kingdom: sexually transmitted diseases. Br F Venereal Dis 1983;59:134-7.

6 Rodriguez-Pichardo A, Aznar J, Camacho F, Borobio MV Perea EJ. Sexually transmitted diseases in homosexual males in Seville, Spain. Genitourin Med 1991;6:335-8.

7 Short DL, Stockman DL, Wolinsky SM et al. Comparative rates of sexually transmitted diseases among heterosexual men, homosexual men, and heterosexual women. Sex Transm Dis 1984;11:271-4.

8 Greco D, Giuliani M, Suligoi B, Panatta M, Giannetti A. Sexually transmitted diseases in Italy: cliical returns 
versus statutory notifications. Genitourinary Med 1990;66:383-6.

9 Hippeläinen $M$, Yliskoski $M$, Saarikoski $S$, Syrjänen $S$, Syrjänen $K$. Genital human papillomavirus lesions of the male sexual partners: the diagnostic accuracy of peniscopy. Genitourin Med 1991;67:291-6.

10 Gross G, Ikenberg H, Gissmann L, Hagedorn M. Papillomavirus infection of the anogenital region: correlation between histology, clinical picture, and virus type. Proposal of a new nomenclature. $f$ Invest Dermatol 1985;85:147-52.

11 Krebs HB, Schneider V. Human papillomavirus associated lesions of the penis: colposcopy, cytology and histology. Obstet Gynecol 1987;70:294-304.

12 Koutsky LA, Galloway DA, Holmes KK. Epidemiology of genital human papillomavirus infection. Epidemiol Rev genital human pap

13 Beckmann AM, Sherman KJ, Myerson D, et al. Comparative virologic studies of condylomata acuminata reveal lack of dual infections with human papillomaviruses. $\mathscr{f}$ Infect Dis 1991;163:393-6.

14 Wilbur DC, Reichman RC, Stoler MH. Detection of infection by human papillomavirus in genital condylomata: a comparison study using immunochemistry and in situ nucleic acid hybridization. Am $\mathcal{f}$ Clin Pathol 1988;89:505-10.

15 Nuovo GJ, Friedman D, Richart RM. In situ hybridization analysis of human papillomavirus DNA segregatior pattern in lesions of the female genital sect Gymecol Oncol 1990;36:256-62.

6 Buscema J, Naghashfar Z, Sawada E et al. The predominance of human papillomavirus type 16 in vulvar neoplasia. Obstet Gynceol 1988;71:601-6

17 Saiki RK, Gelfand DM, Stoffel S et al. Primer-directed enzymatic amplification of DNA with a thermostable DNA polymerase. Science 1988;239:487-9

18 Schiffman MH, Bauer HM, Lorincz AT et al. Comparison of southern blot hybridization and polymerase chain reaction methods for the detection of human papillomavirus DNA. $\mathcal{f}$ Clin Microbiol 1991;29:573-7

19 Brule van den AIC Meijer CJI M Bals V, Kenemans P, Walboomers JMM. Rapid detection of human papillomavirus in cervical scrapes by combined general primer mediated and type-specific polymerase chain reaction. $\mathcal{F}$ Clin Microbiol 1990;28:2739-43.

20 Bauer HM, ViTing MS, Greer CE et al. Genital human papillomavirus infection in female university students as determined by a PCR-based method. $7 A M A$ 1991;265: 472-7.

21 Wikström A, Hedblad MA, Johansson B et al. Then acetic acid test in evaluation of subclinical genital papillomavirus infection: A comparative study of penoscopy, histopathology, virology and scanning electron microshistopathology, virology and scanning

22 Meyer MP, Markiw CA, Matuscak RR et al. Detection of human papillomavirus DNA in genital lesions by using a modified commercially available in situ hybridization assay. F Clin Microbiol 1991;29:1308-11.

23 Barrasso R, De Brux J, Croissant O, Orth G. High prevalence of papillomavirus-associated penile intraepithelial neoplasia in sexual partners of women with cervical intraepithelial neoplasia. $N$ Engl $f$ Med 1987;317: 916-23.

24 Wickenden C, Hanna N, Taylor-Robinson D et al. Sexual transmission of human papillomavirus in heterosexual and male homosexual couples, studied by DNA hybridisation. Genitourin Med 1988;64:34-8.

25 Gravitt $\mathrm{P}$, Hakenewerth A, Stoerker J. A direct comparison of methods for use in widespread screening of human of methods for use in widespread screening of human

26 Sawchuk WS. Ancillary diagnostic tests for detection of human papillomavirus. In: Goldfarb MT, Reid R, eds. Human Papillomavirus Infection London, WB Saunders. 1991:277-86.

27 Roman A, Fife KH. Human papillomaviruses: are we ready to type? Clin Microb Rev 1989;2:166-90. 